This article is distributed under the terms of the Creative Commons Attribution 3.0 PL (c) Copyright by Uniwersytet Warszawski Katedra Studiów Interkulturowych Europy Środkowo-Wschodniej \& individual articles to their Authors

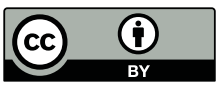

doi: 10.32612/uw.2543618X.2019.pp.91-115

Przegląd Środkowo-Wschodni, 4, 2019

ISSN 2543-618X elSSN 2545-1324

Nr art. 20190406

Data przesłania: 11.03.2018

Аляксандр Горны

Data akceptacji: 23.05.2018

Гродзенскі дзяржаўны ўніверсітэт імя Янкі Купалы

litvin_horny@tut.by

ORCiD: 0000-0002-2652-8837

\title{
«Беларуская санацыя» ў Польшчы (1928-1937): паміж канфрантацыяй і лаяльнасцю
}

\section{„Sanacja białoruska” w Polsce (1927-1937): między konfrontacją a lojalnością}

W okresie międzywojennym w białoruskim ruchu narodowym na zachodniej Białorusi w Polsce istniało wiele prądów politycznych. Wśród nich była „białoruska sanacja” („grupa Łuckiewicza-Ostrowskiego"), która powstała po zdelegalizowaniu przez władze polskie Białoruskiej Włościańsko-Robotniczej Hromady. Przedstawiciele „białoruskiej sanacji” postulowali porzucenie radykalnej walki politycznej i rozpoczęcie poszukiwania kompromisu z władzami polskimi w celu zachowania istniejących białoruskich organizacji kulturalnych i oświatowych. Takie poglądy wyznawały m.in. organizacje Centrasajuz i Towarzystwo Białoruskiej Oświaty. Jednocześnie „białoruska sanacja" była dość krytycznie ustosunkowana wobec polityki polonizacyjnej i występowała w roli "konstruktywnej opozycji" wobec władz polskich. Przyczyną upadku „białoruskiej sanacji” były wewnętrzne nieporozumienia między przywódcami tego obozu politycznego.

Słowa kluczowe: białoruski ruch narodowy, Zachodnia Białoruś, Polska międzywojenna, "białoruska sanacja", grupa Łuckiewicza-Ostrowskiego

У міжваенны перыяд у беларускім нацыянальным руху ў Заходняй Беларусі ў складзе Польшчы існаваў шэраг палітычных кірункаў, у межах якіх распрацоўваліся асобныя стратэгіі паводзін і розныя праекты будучыні беларускіх зямель. Кожны з гэтых кірункаў 
абапіраўся на пэўныя грамадскія рэсурсы, меў кола сваіх прыхільнікаў і розныя крыніцы фінансавай падтрымкі.

Калі ў пачатку 1920-х гадоў дамінаваў нацыянальна-дэмакратычны дыскурс і настальгія па нерэалізаванай дзяржаўнасці ў выглядзе Беларускай Народнай Рэспублікі, то ўжо ў сярэдзіне 1920-х гадоў на першае месца пачаў выходзіць леварадыкальны кірунак 3 яго прасавецкім пафасам. Аднак стаўка часткі беларускага грамадства на левую ідэалогію ў выглядзе масавай падтрымкі Беларускай сялянскаработніцкай грамады (БСРГ) у сярэдзіне 1920-х гадоў не прынесла пазітыўных вынікаў. Разгром гэтай парты ў 1927 годзе прывёў беларускі нацыянальны рух да глыбокага арганізацыйнага крызісу.

Пасля ліквідацыі БСРГ многія беларускія актывісты старэйшага пакалення прыйшлі да думкі аб немэтазгоднасці радыкальных выступленняу і пачалі дыялог з польскімі ўладамі. Ва ўмовах рэпрэсій перад лідарамі нацыянальнага руху ўзнікла праблема захавання, па-першае, існуючых беларускіх культурна-асветных устаноў, не звязаных з палітыкай, а па-другое, г. зв. «спадчыны Грамады» - вялікай сеткі правінцыйных актывістаў. Таму частка найбольш уплывовых дзеячаў БСРГ лічыла вартым прызнаць суверэнітэт Польшчы на заходнебеларускія землі, адмовіцца ад радыкальнай дзейнасці і знайсці пэўны кампраміс з санацыйнымі ўладамі [пол. sanacja (ад лац. sanatio 'аздараўленне') - размоўная назва лагера прыхільнікаў Ю. Пілсудскага ў 1926-1939 гадах, якая ўзнікла пад лозунгам «маральнага аздараўлення» грамадскага жыцця, які абвяшчаў Ю. Пілсудскі падчас падрыхтоўкі і правядзення Майскага перавароту 1926 года. - Рэд.] па «беларускім пытанні». Такім чынам, у грамадска-палітычным жыцці Заходняй Беларусі паступова з'явіўся праўрадавы палітычны кірунак, які ў тагачасным палітычным лексіконе атрымаў назву «беларуская санацыя», альбо «група Луцкевіча-Астроўскага».

Перад разглядам праблемы фарміравання «беларускай санацыі» неабходна заўважыць, што ў гістарыяграфіi да сённяшняга часу не існуе вызначэння дакладнай даты, ад якой трэба адлічваць пачатак 
гэтага палітычнага руху. У прыватнасці, прадстаўнік даваеннай гістарыяграфіі М. Левін, прытрымліваючыся тагачасных савецкіх установак, лічыў, што «беларуская санацыя» ўзнікла яшчэ падчас дзейнасці БСРГ, калі ў склад партыі былі «ўведзены польскай ахранкай старыя дзеячы беларускага нацыяналізму» ${ }^{1}$. Няма сумнення, што падобная ацэнка была прадыктавана палітычнай кан'юнктурай. Больш аб'ектыўна да праблемы генезісу «беларускай санацыі» пачалі ставіцца ўжо прадстаўнікі пасляваенай гістарычнай навукі. Яны бачылі яе пачатак ва ўнутраным расколе Таварыства беларускай школы (ТБШ) у 1929 годзе, калі адна частка дзеячаў таварыства заклікала захаваць яго культурна-асветны характар, а другая - пашыраць палітычную дзейнасць ${ }^{2}$. Гэтае сцвярджэнне прысутнічае ў некаторых працах сучасных аўтараў³. Акрамя гэтага, беларускі гісторык А. Сідарэвіч лічыць, што зыходным пунктам пачатку сумеснай дзейнасці А. Луцкевіча і Р. Астроўскага па стварэнні праўрадавай групы сталі падзеі ў Віленскай беларускай гімназіі ў лютым 1929 года, звязаныя 3 выключэннем $з$ яе камуністычных актывістаў4. У сваю чаргу, Я. Вапа першымі мерапрыемствамі, якія прадставілі «беларускую санацыю» ў палітычным жыцці, называе «акадэміі» (урачыстыя мерапрыемствы) да 10-годдзя смерці І. Луцкевіча і 400-годдзя выдання першага Статута ВКЛ, праведзеныя ў лістападзе 1929 года 5 .

${ }^{1}$ М. Левин, Белорусская санация (Луиякевич-Островский) [в:] Политические партии в Польше, Западной Белоруссии и Западной Украине, ред. С. Скульский, Минск 1935, с. 280.

2 У. Ладысеў, Шлях да свабоды: з гісторыі рэвалюиыйна-вызваленчага руху у Заходняй Беларусі у 1919-1939 г2., Мінск 1978, с. 69-70; В. Полуян, Революиионно-демократическое движение в Западной Белоруссии (1927-1939 г2.), Минск 1978 , с. $122-126$.

3 У. Ладысеў, Беларуская санацыя [у:] Энщыклапедыя гісторыі Беларусі. У 6 m. Т. 1, рэдкал.: М. В. Біч [і інш.], Мінск 1993, с. 407.

${ }^{4}$ А. Сідарэвіч, Хроніка пераломнага часу: Антон Луиякевіч як ідэолаг і правадыр нацыянал-фашызму і нацылянал-дэмакратыі, «Дзеяслоў» 2004, № 8, с. 176.

${ }^{5}$ E. Wappa, Okoliczności powstania Centralnego Zwiazku Białoruskich Organizacji i Instytucji Kulturalno-Oświatowych (,, Centrasajuzu”) i jego udziat w wyborach 1930 r., „Białoruskie Zeszyty Historyczne” 1994, t. 1, s. 64. 
Аднак, на маю думку, патрабуюць больш глыбокага асэнсавання ўзаемаадносіны паміж былымі кіраўнікамі БСРГ у постграмадоўскі перыяд, звязаныя са зменай тактыкі барацьбы ў тагачасных палітычных умовах.

Фактычна карані будучага палітычнага кірунку, які атрымаў назву «беларуская санацыя», неабходна шукаць ужо ў перыяд ліквідацыі БСРГ польскімі ўладамі і судовага працэсу над яе актывам. Некаторыя з арыштаваных па справе БСРГ дзеячаў, разлічваючы на хуткае вызваленне, задавалі заканамернае пытанне: як далей працаваць з рэшткамі Грамады і тымі арганізацыямі, якія былі ёй падкантрольныя? Падобнае пытанне актыўна ўзнімалася падчас турэмных прагулак альбо сустрэч у арыштанцкіх пакоях падчас судовага працэсу. Пры такіх размовах шырока абгаворвалася адмова тых дзеячаў, якія застануцца на волі, ад радыкальных палітычных метадаў барацьбы і пераключэнне іх на культурна-асветную дзейнасць дзеля захавання ранейшых здабыткаў. Як успамінаў А. Луцкевіч, адным з аўтараў ідэі аддзялення культуры ад палітыкі выступаў былы старшыня БСРГ Б. Тарашкевіч. Неабходна адзначыць, што гэтая інфармацыя змяшчаецца ў двух храналагічна розных уласнаручных дакументах А. Луцкевіча, што дае падставы лічыць іх набліжанымі да праўды ${ }^{6}$. Акрамя А. Луцкевіча, падобныя сведчанні прыводзіў і былы юрысконсульт Грамады Ф. Акінчыц: «У гутарках са мной ён [Тарашкевіч. - А. Г.] развіваў тую думку, што па звальненні трэба заняцца культурна-асветніцкаю працаю ў нацыянальным кірунку» ${ }^{7}$. Як А. Луцкевіч, так і Ф. Акінчыц падкрэслівалі, што на ролю кіраўніка будучай культурнай работы быў абраны Р. Астроўскі. Неўзабаве Б. Тарашкевіч, праўдападобна, пад уздзеяннем рэкамендацый з боку КПЗБ, заняў

6 Беларускі дзяржаўны архіў-музей літаратуры і мастацтва (БДАМЛіМ), ф. 3, воп. 1, спр. 270 «Дакументы грамадскага суда Р. Астроўскага супраць А. Луцкевіча, У. Самойлы, А. Трэпкі (1934-1935 гг.)», арк. 7; А. Луцкевіч, Да гісторыі беларускага руху, Białystok, Vilnius 2010, с. 256.

${ }^{7}$ Ф. Акінчыц, Чаму гэта так сталася?, Вільня 1931, с. 9. 
адносна гэтага кірунку варожую пазіцыю і актыўна крытыкаваў адыход часткі асуджаных па справе БСРГ ад радыкальнай тактыкі змагання.

Адмова ад радыкальнай палітычнай дзейнасці часткі актыву БСРГ таксама была звязана са справай вызвалення кіраўніцтва партыі, якое падчас судовага працэсу 23 лютага - 22 мая 1928 года было асуджана на значныя турэмныя тэрміны. Гэтая акалічнасць, безумоўна, штурхала тых, хто застаўся на волі, да наладжвання адносін з польскімі палітычнымі коламі. Р. Астроўскі ў сваім лісце да Б. Тарашкевіча ў жніўні 1929 года прыгадваў, што пасля вызвалення да яго звярнуліся некаторыя польскія палітыкі ў справе паляпшэння польска-беларускіх адносін. Астроўскі заявіў ім, што любыя перагаворы з уладамі ў гэтым кірунку могуць весціся толькі пры ўмове датэрміновага вызвалення кіраўнікоў БСРГ ${ }^{8}$ Пасрэдніцкую ролю ў гэтым працэсе ўзялі на сябе прадстаўнікі г. зв. «віленскіх дэмакратаў», якія аб'ядноўваліся вакол газеты Kurjer Wileński. Можна дапусціць, што менавіта дзякуючы гэтым захадам у сакавіку 1929 года, пасля апеляцыйнага працэсу, кіраўнікам БСРГ быў фактычна ў два разы зменшаны тэрмін зняволення.

Падзел былога актыву БСРГ на два розныя лагеры стаў відавочны ўжо падчас перадвыбарчай кампаніі ў польскі парламент у пачатку 1928 года. Б. Тарашкевіч, С. Рак-Міхайлоўскі і П. Мятла, знаходзячыся ў турме, падтрымалі пракамуністычныя спісы. У той жа час Р. Астроўскі і Я. Шнаркевіч праігнаравалі левыя сілы і пачалі супрацоўнічаць 3 Выбарчым камітэтам беларускіх сялян і работнікаў на чале з Я. Станкевічам, які прытрымліваўся нацыянальна-дэмакратычнай і памяркоўнай праграмы ${ }^{9}$. Да іх таксама далучыўся адзін з былых лідараў БСРГ на тэрыторыі Навагрудскага

${ }^{8}$ Lietuvos centrinis valstybès archyvas (LCVA), f. 131, ap. 2, b. 1645 ,Sprawy osób oskarżonych za działalność komunistyczną. Taraszkiewicz Bronisław (19311933)", 1. 329.

9 Białorusini, „Sprawy Narodowościowe” 1928, nr 1, s. 65-66; Mniejszości narodowe w wyborach do Sejmu i Senatu w r. 1928, Warszawa 1928, s. 55. 
ваяводства М. Чатырка, які ў студзені 1927 года быў арыштаваны за антыдзяржаўную дзейнасць, але неўзабаве вызвалены.

22 мая 1928 года, паводле пастановы суда па справе БСРГ, А. Луцкевіч, Р. Астроўскі, Я. Шнаркевіч і А. Коўш былі апраўданы і вызвалены з-пад арышту. Выхад на свабоду даў ім магчымасць больш актыўна дзейнічаць у кірунку стварэння новага грамадскага руху культурна-памяркоўнага характару. Першыя крокі былі зроблены ў царкоўнай сферы. У жніўні 1928 года А. Коўш, Р. Астроўскі і М. Чатырка ад беларускай меншасці былі ўключаны ў склад Мітрапалітальнай рады - дарадчага органа пры кіраўніку Польскай праваслаўнай царквы мітрапаліце Дыянісію ${ }^{10}$. У беларускім левым асяроддзі падобныя кантакты Р. Астроўскага і М. Чатыркі, якія раней выказвалі атэістычныя погляды, 3 праўрадавай царкоўнай іерархіяй выклікалі збянтэжанасць ${ }^{11}$.

Менавіта ў гэты перыяд на парадак дня выйшла праблема захавання ТБШ. 28 жніўня 1928 года на загад віленскага старосты была закрыта галоўная ўправа ТБШ па прычыне ангажаванасці ў яе дзейнасць «антыдзяржаўных элементаў». Дэлегацыі членаў ТБШ, у склад якой уваходзілі Р. Астроўскі, Я. Шнаркевіч, А. Трэпка і К. Крук, віленскія ваяводскія ўлады заявілі, што лёс арганізацыі залежыць ад выдалення 3 яе пракамуністычных дзеячаў. Замест галоўнай управы было дазволена стварыць паўнамоцную камісію, якая павінна была падрыхтаваць правядзенне агульнага з'езда ТБШ. Пасля гэтых падзей унутры арганізацыі пачалася моцная барацьба тых дзеячаў, якія жадалі працягваць палітычную барацьбу, і прыхільнікаў «санацыі» таварыства ${ }^{12}$.

Першая спроба правядзення «санацыі» ў беларускіх арганізацыях была зроблена ў Віленскай беларускай гімназіі (ВБГ). 14 кастрычніка 1928 года падчас лекцыі Я. Станкевіча некаторыя вучні

\footnotetext{
${ }^{10}$ А. С., Мітрапалітальная Рада, «Беларуская зарніца» 1928, № 1, с. 9.

${ }^{11}$ Узмацненьне клерыкалізму, «Рэха працы» 1928, № 5, с. 2.

12 Białorusini, „Sprawy Narodowościowe” 1928, nr 3-4, s. 421.
} 
гімназіі леварадыкальных поглядаў спрабавалі яе сарваць. На загад інспектара ВБГ Р. Астроўскага яны былі выключаны з навучальнай установы ${ }^{13}$. Гэты выпадак набыў значны грамадскі рэзананс. Ужо 24 кастрычніка беларуская левая прэса паведамляла аб узнікненні ўнутры беларускага палітычнага поля «санацыйнага» кірунку ${ }^{14}$. У лістападзе член беларускага пасольскага клуба «Змаганне» Ф. Валынец, выступаючы з трыбуны Сейма Польшчы, фактычна ўпершыню адкрыта назваў прозвішча Р. Астроўскага як «прыслужніка польскага фашызму» ${ }^{15} .3$ снежня 1928 года ў прэсе была першы раз выкарыстана назва «беларуская санацыя» адносна Р. Астроўскага і яго прыхільнікаў (беларускія нацыянальна-дэмакратычныя газеты сталі выкарыстоўваць гэты тэрмін значна пазней - толькі летам 1929 года $)^{16}$. У лютым 1929 года заходнебеларускія леварадыкальныя газеты і выданні ў савецкай Беларусі пачалі ўключаць у гэтую групу і А. Луцкевіча, бо ён не зрабіў публічнага асуджэння дзейнасці Р. Астроўскага. А. Луцкевіч актыўна супраціўляўся палітызацыі ТБШ і выступаў за захаванне яго асветных функцый, чым салідарызаваўся 3 дзеячамі «беларускай санацыі» ${ }^{17}$.

Варта заўважыць, што названая вышэй група дзеячаў не мела ўласнай назвы. Як ужо адзначалася, палітычныя праціўнікі з боку нацыянальна-дэмакратычных і леварадыкальных арганізацый далі гэтай групе найменне «беларуская санацыя». Таксама ў гэты перыяд узнікла іншая, палітычна нейтральная назва групы, утвораная ад прозвішчаў яе найбольш уплывовых дзеячаў - «група Луцкевіча-Астроўскага». Падобную назву, напрыклад, афіцыйна выкары-

${ }^{13}$ Białorusini, „Sprawy Narodowościowe” 1928, nr 5, s. 539.

${ }^{14}$ Полярызаџыя сілаў, «Слова працы» 1928, № 7, с. 1.

${ }^{15}$ Sejm Rzeczypospolitej Polskiej. Okres II. Sprawozdanie stenograficzne z 31 posiedzenia z dnia 16 listopada 1928 r., Warszawa 1928, s. 40.

${ }^{16}$ Наша хроніка. Беларуская санаџьыя ў новай ролі, «Да працы» 1928, № 2, с. 3; Z biełaruskaha žyćcia, „Biełaruskaja krynica” 1929, nr 23, s. 2.

17 А. Луцкевіч, ор. cit., с. 257; А. Сталевіч, Польскі фашызм ратуецица бельмм тэрорам, «Савецкая Беларусь» 1929, № 38, с. 1. 
стоўвалі польскія ўлады ў сваіх справаздачах аб грамадска-палітычным жыцці ў Заходняй Беларусі ${ }^{18}$. Разам 3 гэтым, абедзве назвы групы ўстойліва замацаваліся ў беларускай гістарыяграфіi, што дазваляе правамерна выкарыстоўваць іх у гэтым даследаванні.

У 1929 годзе прысутнасць групы Луцкевіча-Астроўскага ў культурна-асветным жыцці беларусаў Польшчы стала больш прыкметнай. Шырокі рэзананс атрымалі падзеі ў ВБГ у лютым 1929 года. Тады дырэктар гімназіі Р. Астроўскі выключыў з навучальнай установы каля 65 вучняў, якіх падазравалі ў камуністычнай агітацыі, працягваючы праводзіць лінію аддзялення школы ад палітыкі ${ }^{19}$. 19 мая падчас нелегальнага з'езда ТБШ са складу арганізацыі былі выключаны прыхільнікі «санацыі» таварыства А. Луцкевіч, Р. Астроўскі, К. Крук, А. Коўш і інш., якіх абвінавацілі ў «згодніцтве» ${ }^{20}$. Аднак, нягледзячы на гэта, група Луцкевіча-Астроўскага паступова пашырала кола сваіх прыхільнікаў, пераважна за кошт вучнёўскай моладзі і студэнцтва. Пачынаў праяўляцца абрыс тых беларускіх культурных арганізацый і ўстаноў (напрыклад, ВБГ, Беларускага дабрачыннага таварыства), дзе «беларуская санацыя» цвёрда ўтрымлівала свае пазіцыі. Пры гэтым дзеячы адзначанай групы 3 мэтай пашырэння ўласных ідэй мелі намер уключыцца ў грамадска-палітычнае жыццё Заходняй Беларусі. Першай праявай дзейнасці «беларускай санацыі» стала выданне са снежня 1929 года ўласнага друкаванага органа - газеты «Наперад», у рэдакцыю якой уваходзілі А. Луцкевіч, Р. Астроўскі, К. Крук, А. Трэпка, Я. Шнаркевіч, М. Сіняўскі і нават беларускі дэпутат парламента Латвіі У. Пігулеўскі ${ }^{21}$.

${ }^{18}$ LCVA, f. 51, ap. 7, b. 979 „Redagowanie czasopisma pod tytułem «Hołas prawosławnoho Biełarusa» (1932)”, 1. 1; ibidem, f. 53, ap. 23, b. 1074 „Sprawozdania sytuacyjne z życia społecznego i politycznego m. Wilno (1931)", 1. 183, 185 ant.

${ }^{19}$ Да падзеяў у Віленскай беларускай гімназіі, «Бальшавік» 1929, № 3, с. 12.

20 А. Вабішчэвіч, Наџьиянальна-культурнае жыциё у Заходняй Беларусі (1921-1939 г2.): дысертацыя доктара гістарычных навук, Брэст 2010, с. 79-80.

${ }^{21}$ Ад рэдакиы 
Каб заручыцца падтрымкай былых сяброў БСРГ, палітычны кірунак газеты «Наперад» быў акрэслены як радыкальны. Але ніякіх радыкальных патрабаванняў на яе старонках не агучвалася. Наадварот, прыхільнікі групы Луцкевіча-Астроўскага праз сваю газету спрабавалі пашырыць ідэю «пазітыўнай працы». Аналіз матэрыялаў «Наперад» дазваляе вызначыць асноўныя кампаненты гэтай ідэі:

- ажыццяўленне нацыянальна-культурнай дзейнасці канстытуцыйным шляхам пры павазе да польскага заканадаўства;

- шырокая праца ў галіне нацыянальнага выхавання беларускага насельніцтва перш за ўсё праз родную школу і культурныя арганізацыі;

- пошук кампрамісаў з уладамі і патрабаванне ад іх прызнання таго факта, што беларусы з'яўляюцца часткай польскай грамадзянскай супольнасці і таму маюць права на падтрымку свайго нацыянальна-культурнага развіцця з польскіх дзяржаўных фондаў ${ }^{22}$.

У далейшым ідэя «пазітыўнай працы» ў той або іншай ступені чырвонай ніткай праходзіла праз усю дзейнасць групы. Паказальнымі ў гэтым плане з'яўляюцца словы Р. Астроўскага, выказаныя ім у 1931 годзе перад польскімі грамадскімі дзеячамі на пасяджэнні Klubu Społecznego y̆ Вільні: «Беларусы шукаюць заспакаення сваіх патрэбаў у рамках польскай дзяржаўнасці ${ }^{23}$. Са свайго боку А. Луцкевіч абгрунтоўваў ідэю «пазітыўнай працы» і лаяльнасці да ўлад наступным чынам: «Трэба выкарыстоўваць усякія магчымасці, каб змагацца 3 дэнацыяналізацыяй» ${ }^{24}$.

Прытрымліваючыся ідэі «пазітыўнай працы» група Луцкевіча-Астроўскага не адмаўлялася ад лозунга незалежнасці Бела-

${ }^{22}$ Ня слоў, а дзела!, «Наперад» 1929, № 3, с. 1; Сваімі сіламі, «Наперад» 1930, № 6, с. 1; Эра [Р. Астроўскі], Яшчэ адна - можа апошняя - спроба, «Наперад» 1930, № 21, c. 1 .

${ }^{23}$ Беларуская справа і польскае грамадзянства, «Беларускі звон» 1931, № 7, с. 1.

${ }^{24}$ В. Склубоўскі, 3 мінульхх год, «Ніва» 1982, № 25, с. 4. 
русі. Аднак незалежнасць і аб’яднанне беларускіх зямель, паводле праграмных дакументаў «беларускай санацыі», залежалі ад спрыяльнай міжнароднай абстаноўкі ў рэгіёне і адкладваліся на нявызначаны тэрмін. У кароткатэрміновай перспектыве група Луцкевіча-Астроўскага прапаноўвала ўрэгуляваць палітычнае жыццё беларускага народа ў тых дзяржавах, дзе ён пражываў, у тым ліку і ў Польшчы. У адпаведнасці з гэтым выказвалася ідэя вылучэння тэрыторыі з большасцю беларускага насельніцтва (Віленскага, Навагрудскага, Палескага і часткі Беластоцкага ваяводства) у асобную адміністрацыйную адзінку польскай дзяржавы і надання ёй шырокай аўтаноміi ${ }^{25}$. Калі патрабаванні аўтаноміі на той перыяд былі фактычна бесперспектыўныя, то жаданне аб'яднаць заходнебеларускія ваяводсты ў 1930-х гадах мела пад сабой рэальны грунт. Так, у 1930 годзе Кадыфікацыйная камісія Польшчы распрацавала праект злучэння тэрыторый Віленскага, Навагрудскага і часткі Беластоцкага ваяводства ў адно ваяводства. Ён быў пазітыўна ацэнены прадстаўнікамі «беларускай санацыі», аднак яго далейшая рэалізацыя па невядомых прычынах была адкладзена ${ }^{26}$.

Адным 3 асноўных элементаў палітычнай праграмы групы Луцкевіча-Астроўскага была яе антыкамуністычная і антысавецкая накіраванасць. «Беларуская санацыя» востра асуджала ўсталяваны ў БССР сталінскі палітычны рэжым, асабліва за згортванне палітыкі беларусізацыі і правядзенне калектывізацыі ў сельскай гаспадарцы ${ }^{27}$. Праз падобную крытыку група Луцкевіча-Астроўскага імкнулася пазбавіць заходнебеларускую інтэлігенцыю тых «міра-

${ }_{25}$ У. Ладысеў, П. Брыгадзін, Паміж Усходам і Захадам. Станаўленне дзяржаўнасиі і тэрытарыяльнай иэласнасці Беларусі (1917-1939 г2.), Мінск 2003, c. 298.

${ }^{26}$ Нацыянальны архіў Рэспублікі Беларусь (НАРБ), ф. 242п, воп. 1, спр. 30 «Материалы по национально-освободительному движению в Западной Белоруссии и газета „Большевик” (1924-1935 гг.)», арк. 60.

${ }_{27}^{27}$ Бараиьба з беларускасьияй у БССР, «Наперад» 1930, № 19, с. 2; «Калгасы»» $\check{y}$ БССР, «Наперад» 1930, № 8, с. 1; Цень Азэфаa, «Наперад» 1930, № 7, с. 1. 
жоў» адносна савецкай Беларусі, якія склаліся яшчэ ў часы дзейнасці БСРГ.

Нягледзячы на агульную кампрамісную пазіцыю адносна ўлад, група Луцкевіча-Астроўскага дазваляла сабе выказваць некаторыя крытычныя заўвагі ў адрас урадавай палітыкі на г. зв. Kresach Wschodnich. Асабліва гэта датычылася праблемы паланізацыі, звужэння беларускага школьніцтва і пашырэння вайсковага асадніцтва. Польскія ўлады ў справаздачах вызначалі палітычны кірунак групы Луцкевіча-Астроўскага як «канструктыўная апазіцыя» (opozycja rzeczowa), падкрэсліваючы такім чынам, з аднаго боку, яе кампрамісны характар, а з другога - крытычныя адносіны да польскай палітыкі ў Заходняй Беларусі ${ }^{28}$. Падобныя назіранні сустракаюцца і ў іншых крыніцах. Так, віленскія ваяводскія ўлады адзначалі, што група Луцкевіча-Астроўскага мела пэўны недавер да польскай палітыкі па «беларускім пытанні», але адначасова не жадала зрываць супрацоўніцтва з урадавымі структурамі. На іх думку, разрыў узаемаадносін з уладамі і адсутнасць падтрымкі з боку ўрада маглі прывесці да канчатковага заняпаду групы ${ }^{29}$.

У сваёй дзейнасці група Луцкевіча-Астроўскага разлічвала на падтрымку былога актыву БСРГ. Распрацоўваліся планы далучэння да групы былых кіраўнікоў Грамады. Гэта стала магчыма ў красавіку-ліпені 1930 года, калі Б. Тарашкевіч, С. Рак-Міхайлоўскі, П. Мятла, М. Бурсевіч і Ф. Акінчыц паводле памілавання прэзідэнта Польшчы былі вызвалены $з$ турмаў. Прадстаўнікі «беларускай санацыі» пачалі рабіць захады па прыцягненні вызваленых грамадоўцаў да супрацоўніцтва ${ }^{30}$. Аднак толькі Ф. Акінчыц згадзіўся далучыцца да палітычнай платформы групы Луцкевіча-Астроўскага. Сваё рашэнне ён абгрунтаваў тым, што менавіта ў гэтай групе былі

${ }^{28}$ LCVA, f. 51, ap. 7, b. 1008 ,Redagowanie czasopism pod tytułem «Napierad», «Narodny Zwon», «Białoruski Zwon» (1929-1932)”, 1. 14 ant.

${ }^{29}$ Ibidem, f. 53, ap. 23, b. 1075 „Sprawozdania sytuacyjne z życia społecznego i politycznego m. Wilno (1931)", 1. 26-26 ant.

${ }^{30}$ E. Wappa, op. cit, s. 67. 
аб’яднаны «ўсе жывыя сілы, якія нешта рабілі і якія здольныя прынесці карысць беларускай грамадскасці» ${ }^{31}$.

У 1928-1930 гадах група Луцкевіча-Астроўскага паставіла пад уласны кантроль шэраг культурна-асветных арганізацый і ўстаноў. Для каардынацыі іх дзейнасці кіраўніцтвам групы было вырашана стварыць цэнтралізаваную структуру з распарадчымі функцыямі. 11 жніууня 1930 года віленскі ваявода зацвердзіў статут новаўтворанай арганізацыі, якая атрымала назву Цэнтральны саюз беларускіх культурна-асветных і гаспадарчых арганізацый і ўстаноў, скарочана - Цэнтрасаюз. Згодна са статутам, вышэйшым органам кіраўніцтва Цэнтрасаюза лічылася галоўная рада, сесія якой склікалася адзін раз на год. Выканаўчыя функцыі выконваў прэзідыум галоўнай рады на чале са старшынёй. Арганізацыі, якія ўваходзілі ў Цэнтрасаюз на аўтаномных правах, павінны былі дэлегаваць сваіх прадстаўнікоў у кіраўнічыя органы ${ }^{32}$. Сваіх дэлегатаў у Цэнтрасаюз накіравалі наступныя таварыствы і ўстановы: Беларускае навуковае таварыства, Беларускі настаўніцкі саюз, Беларускае дабрачыннае таварыства, Беларускі гаспадарчы звяз, беларуская кнігарня ў Маладзечне, кааператывы Spółdzielca i «Пчала», рэдакцыя часопіса «Саха», Віленская, Навагрудская, Клецкая беларускія гімназіi ${ }^{33}$.

На думку гісторыка Ю. Туронка, Цэнтрасаюз стаў своеасаблівым «холдынгам», які аб' ядноўваў шматлікія культурныя арганізацы і ўстановы памяркоўнага характару ${ }^{34}$. Аднак фактычна, ствараючы гэтую арганізацыю, група Луцкевіча-Астроўскага мела больш шырокія палітычныя намеры. Цэнтрасаюз павінен быў стаць альтэрнатывай віленскаму БНК, які кантраляваўся беларускімі

${ }^{31}$ Ф. Акінчыц, Пісьмо ў рэдакцыю, «Наперад» 1930, № 27, с. 4.

${ }^{32}$ Статут Цэнтральнага Саюзу Беларускіх Культурна-Прасьветных і Гаспадарскіх Арганізацыяу і Інстытуцыяў, Вільня 1930, с. 3-6.

${ }^{33}$ Sprawozdanie z życia mniejszości narodowych za II i III kwartat 1930 r., Warszawa 1930, s. 67.

${ }^{34}$ Ю. Туронак, Мадэрная гісторыя Беларусі, Vilnius 2006, с. 288. 
хадэкамі ${ }^{35}$. Разам 3 гэтым, наяўнасць падобнай арганізацыі давала магчымасць больш цэнтралізавана атрымліваць і расходаваць грашовыя субсідыі польскіх улад ${ }^{36}$.

Падчас першай сесіі галоўнай рады Цэнтрасаюза, якая адбылася 27-28 верасня 1930 года, было абрана пастаяннае кіраўніцтва арганізацыі. У яго склад увайшлі А. Трэпка (старшыня), Р. Астроўскі (скарбнік), Ф. Акінчыц (сакратар), С. Кароль, І. Цеханоўскі, Я. Шнаркевіч і Р. Якубёнак. Таксама быў вызначаны пэўны план работы на бліжэйшы час. Сярод іншага планавалася патрабаваць ад улад пашырэння беларускамоўнай адукацыі, адкрыцця беларускіх настаўніцкіх курсаў, выдання беларускіх падручнікаў і інш. Акрамя гэтага, кіраўніцтва Цэнтрасаюза пастанавіла прыняць удзел у найбліжэйшых парламенцкіх выбарах і пачаць работу па ўтварэнні маладзёжнай арганізацыі ${ }^{37}$. Аднак большасць з запланаваных кіраўніцтвам «беларускай санацыі» мерапрыемстваў у 1930-1931 гадах не была рэалізавана ${ }^{38}$.

У цэлым, дзейнасць Цэнтрасаюза, якая праходзіла пераважна ў рамках віленскага культурнага асяроддзя, не карысталася значнай падтрымкай з боку насельніцтва і пастаянна крытыкавалася беларускімі левымі і нацыянальна-дэмакратычнымі арганізацыямі. Адной з прычын стагнацыі Цэнтрасаюза было звужэнне фінансавых датацый з боку польскіх улад. Ужо ў лістападзе 1931 года кіраўніцтва арганізацыі ўзняло пытанне аб яе ліквідацыі, што, аднак, не было падтрымана іншымі дзеячамі ${ }^{39}$.

${ }^{35}$ А. Латышонак, Я. Мірановіч, Гісторыя Беларусі ад сярэдзіны XVIII cm. да пачатку XXI cm., Białystok, Vilnius 2010, с. 185.

${ }^{36}$ А. Луцкевіч, op. cit.,c. 258.

${ }^{37}$ LCVA, f. 53, ap. 23, b. 2078 „Akta w sprawie rejestracji i likwidacji związków i stowarzyszeń (statuty, sprawozdania, protokoły, korespondencja). Związek białoruskich kulturalno-oświatowych i gospodarczych organizacji i instytucji (1928-1937)", 1. 58; 1-ая сэсія Галоўнай Рады Беларускага «Цэнтрасаюзу», «Наперад» 1930, № 27, с. 2.

${ }_{38}$ Цэнтрасаюз $і$ яго праца [у:] Беларускі каляндар на 1932 г., Вільня [б. г.], c. $43-44$.

${ }^{39}$ LCVA, f. 53, ap. 23, b. 1074, 1.185 ant. 
Вялікую ролю ў аслабленні арганізацыйнага патэнцыялу Цэнтрасаюза адыграў выхад з яго складу найбольш актыўных дзеячаў па прычыне асабістых непаразуменняў. Так, 21 лютага 1931 года разам з Беларускім гаспадарчым звязам шэрагі Цэнтрасаюза пакінуў Я. Станкевіч ${ }^{40}$. Найбольш значнай стратай стаў выхад з Цэнтрасаюза яго сакратара Ф. Акінчыца, які не падзяляў погляды кіраўніцтва «беларускай санацыі» адносна ролі лідараў БСРГ у беларускім руху і падкрэсліваў іх дэструктыўную дзейнасць ${ }^{41}$. Да таго ж, Ф. Акінчыц пачаў ствараць уласную палітычную арганізацыю «Аб'яднанне» (у некаторых крыніцах назва гэтай арганізацыі памылкова фігуруе як «Адраджэнне». - A. Г.), праграма якой базавалася на ўльтрапаланафільскіх поглядах. Аднак да яго ініцыятывы далучылася невялікая колькасць беларускіх дзеячаў, бо ва ўмовах узмацнення паланізацыі беларускага насельніцтва ўльтрапаланафільскія заклікі Акінчыца выглядалі скарэй дзіўнымі, чым рэальнымі 42.

Фактычны заняпад Цэнтрасаюза і яго недзеяздольнасць прадвызначалі выпрацоўку кіраўніцтвам «беларускай санацыі» новых форм арганізацыйнай працы. Культурныя арганізацыі, якія раней уваходзілі ў Цэнтрасаюз, як, напрыклад, БНТ ці Беларускае дабрачыннае таварыства, мелі вузкапрофільны характар і былі не ў стане закрануць шырокія аспекты культурна-асветнай і грамадскай дзейнасці. Таму асноўная ўвага была звернута на падрыхтоўку да стварэння новай арганізацыі. Восенню 1932 года на сходзе кіруючага цэнтра групы Луцкевіча-Астроўскага (А. Луцкевіч, Р. Астроўскі і А. Трэпка) было прынята рашэнне замест Цэнтраса-

403 жыцьия Цэнтрасаюзу, «Беларускі звон» 1931, № 4, с. 3.

${ }^{41}$ Ф. Акінчыц, Чаму гэта ..., с. 4, 12; Заява, пададзеная гр. Акінчыцам у Прэзыдыюм Б. Ц. Саюзу, «Беларуская праўда. Аднаднёўка» 1931, 12 мая, с. 4.

42 Пра канфрантацыю Ф. Акінчыца 3 кіраўніцтвам Цэнтрасаюза і спробу стварыць уласны палітычны рух гл.: А. Горны, Беларускі Цэнтрасаюз і Ф. Акінчыц (1930-1931 г2.): ад лідарства да варожасиі [w:] Polsko-białoruskie zwiazki językowe, literackie, historyczne i kulturowe: materiaty XIX międzynarodowej konferencji naukowej „Droga ku wzajemności”, red. B. Siegień, Białystok 2014, s. 227-228. 
юза стварыць Таварыства беларускай асветы (ТБА), якое займалася б выключна культурнымі пытаннямі. Пад кіраўніцтвам Астроўскага была створана ініцыятыўная група ў складзе Я. Бартуля, С. Караля, У. Манкевіча і У. Самойлы, якая распрацавала статут арганізацыі і план яе дзейнасці ${ }^{43}$.

Паводле статута ТБА, мэтамі арганізацыі абвяшчаліся праца па развіцці беларускай культуры, пашырэнні школьнай і пазашкольнай асветы сярод моладзі, павышэнні яе маральнага ўзроўню. Дзейнасць таварыства прадугледжвала таксама знаёмства са здабыткамі польскай культуры і культурным жыццём іншых народаў заходнебеларускага рэгіёна. Лакальная структура ТБА павінна была складацца $з$ гурткоў, у склад якіх уваходзіла не менш за пяць членаў таварыства. Кіраўнічым цэнтрам арганізацыі з'яўлялася рада, якая абірала сталы выканаўчы орган - урад (прэзідыум) колькасцю пяць чалавек на чале са старшынёй ${ }^{44}$. Дакументы аб зацвярджэнні новай арганізацы былі пададзены віленскім ваяводскім уладам яшчэ ў верасні 1932 года, але па невядомых прычынах статут ТБА быў зацверджаны толькі 22 снежня 1932 года. Мясцовыя ўлады прыхільна аднесліся да стварэння таварыства. У прыватнасці, віленскае староства раіла аддзелу бяспекі Віленскага ваяводскага ўпраўлення зарэгістраваць ТБА, якое, знаходзячыся пад кантролем «беларускай санацыі», магло скласці супрацьвагу ТБШ ${ }^{45}$.

У пачатку 1933 года быў абраны першы сталы склад прэзідыума ТБА, у які ўвайшлі С. Кароль (старшыня), Я. Бартуль (віцэ-старшыня), У. Самойла (сакратар), У. Манкевіч (скарбнік), Р. Астроўскі

${ }^{43}$ БДАМЛіМ, ф. 3, воп. 1, спр. 270, арк. 20; НАРБ, ф. 242п., воп. 1, спр. 435 «Обзор состояния и деятельности белорусских национально-политических фашистских группировок в Западной Белоруссии и др. (1932-1933 гг.)», арк. 41.

${ }_{44}$ БДАМЛіМ, ф. 3, воп. 1, спр. 31 «Статут Таварыства беларускай асветы ў г. Вільня (1932 г.)», арк. 3-4, 5 адв.

${ }^{45}$ LCVA, f. 53, ap. 23, b. 2005 „Akta w sprawie rejestracji i likwidacji związków i stowarzyszeń (statuty, sprawozdania, protokoły, korespondencja). Towarzystwo Oświaty Białoruskiej (1927-1935)”, 1. 21. 
(старшыня рэвізійнай камісіi). Вялікую арганізацыйную ролю ў ТБА на першым этапе яго існавання адыгрываў У. Самойла, у прыватнай кватэры якога ў Вільні знаходзілася галоўная сядзіба арганізацыі ${ }^{46}$.

У арганізацыйным плане ТБА не ўдалося выйсці па-за межы Віленскага ваяводства і стварыць шырокую сетку гурткоў на прыкладзе ТБШ. На 1935 год прадстаўнікі таварыства не стварылі ніводнага лакальнага гуртка; замест гэтага ў правінцыю накіроўваліся інструктары ТБА, якія праводзілі адукацыйныя лекцыі і дапамагалі мясцоваму актыву адкрываць бібліятэкі-чытальні ${ }^{47}$.

Усяго на пачатак 1934 года было закладзена 33 бібліятэкі-чытальні ТБА, яшчэ 12 чакалі свайго зацвярджэння ўладамі ${ }^{48}$. Прычынамі такой нізкай актыўнасці выступалі розныя фактары: адсутнасць патрэбных фінансавых сродкаў, малалікасць людскіх рэсурсаў, слабая мабілізацыя актывістаў ва ўмовах дзяржаўнай паланізацыі і інш. У некаторых мясцовасцях дзейнасці інструктараў ТБА перашкаджалі прадстаўнікі мясцовых органаў кіравання і самакіравання, якія, не ведаючы аб праўрадава-памяркоўнай арыентацыі таварыства, лічылі яго антыдзяржаўнай структурай ${ }^{49}$. Акрамя гэтага, не апошнюю ролю ў адсутнасці арганізацыйнага патэнцыялу ў ТБА адыграла нарастанне асабістых супярэчнасцей унутры кіруючага цэнтра «беларускай санацыі».

Неабходна заўважыць, што ў пачатку стварэння ТБА ў межах групы Луцкевіча-Астроўскага быў праведзены падзел сфер уплыву. У прыватнасці, Р. Астроўскі засяродзіў сваю працу ў ВБГ і Беларускім дабрачынным таварыстве. А. Луцкевіч асноўную ўвагу надаваў працы ў межах Віленскага беларускага музея і БНТ, а ў кампетэнцыю А. Трэпкі і У. Самойлы ўваходзіла апека над ТБА ${ }^{50}$. Калі

\footnotetext{
${ }^{46}$ БДАМЛіМ, ф. 3, воп. 1, спр. 270, арк. 58.

${ }^{47}$ М. Левин, Белорусская санация..., с. 287.

48 За мінуль год, «Родны край» 1933, № 25, с. 1-2.

${ }^{49}$ LCVA, f. 53, ap. 23, b. 2005, 1. 24.

${ }^{50}$ БДАМЛіМ, ф. 3, воп. 1, спр. 270, арк. 21
} 
ўлічыць, што абодва апошнія дзеячы знаходзіліся ў цесных адносінах з А. Луцкевічам, то атрымлівалася відавочнае размежаванне ўплываў унутры «беларускай санацыі» паміж яе галоўнымі лідарамі. Падобная сітуацыя штурхала А. Луцкевіча і Р. Астроўскага да канфлікту інтарэсаў і барацьбы за павелічэнне ўплываў за межамі сваёй групы.

Прадстаўнікі беларускай і замежнай гістарыяграфіi бачылі адну 3 прычын канфлікту паміж А. Луцкевічам і Р. Астроўскім у сярэдзіне 1930-х гадоў у разыходжаннях адносна далейшай палітычнай тактыкі «беларускай санацыі». Падкрэслівалася, што А. Луцкевіч прапаноўваў трымацца ад улад на адлегласці і збліжацца з беларускімі хадэкамі, у той час як Р. Астроўскі выступаў супраць саюза з БХД i за больш актыўнае супрацоўніцтва 3 рэжымам санацыі ${ }^{51}$. Не адмаўляючы слушнасці гэтых ацэнак, неабходна заўважыць, аднак, што існавала больш глыбокая прычына канфлікту гэтых дзеячаў, якая ляжала ў плоскасці імкненняў да ўзурпацыі ўлады ўнутры групы, асабліва з боку Р. Астроўскага. Паводле сведчанняў У. Самойлы, Р. Астроўскі імкнуўся значна пашырыць уласную сферу ўплыву, цалкам паставіць пад свой кантроль ТБА і выконваць у ім «дыктатарскую» ролю, адсунуўшы на другі план А. Луцкевіча і яго прыхільнікаў. «Ён рашыў захапіць нашу позыцыю, каб пасьля выгадней дыктаваць нам свае варункі [...], каб лягчэй, як ён думаў, змусіць нас прыняць Pax Radoslavia», - успамінаў У. Самойла ${ }^{52}$. Немалаважную ролю ў гэтым працэсе адыгрывала і зацікаўленасць Р. Астроўскага ў больш шырокім кантролі фінансавых субсідый, якія таварыства атрымлівала ад урадавых структур.

Імкненне Астроўскага да кантролю над ТБА выявілася ўжо ў пачатку 1934 года, калі той пачаў праводзіць своеасаблівую «зачыстку»

${ }^{51}$ А. Вабішчэвіч, Таварыства беларускай асветыл [у:] Энцыьклапедыл гісторыі Беларусі. У 6 m. Т. 6, Кн. 1, рэд. Г. Пашкоў, Мінск 2001, с. 488; K. Gomółka, Biatoruskie partie i organizacje prorzadowe w II Rzeczypospolitej, „Białoruskie Zeszyty Historyczne" 1997, t. 7, s. 71.

${ }^{52}$ БДАМЛіМ, ф. 3, воп. 1, спр. 270, арк. 66. 
кіруючых органаў арганізацыі і выдаляць з іх прыхільнікаў А. Луцкевіча ${ }^{53}$. Канчатковы разрыў адносін двух дзеячаў адбыўся падчас агульнага сходу Беларускага навуковага таварыства, скліканага 15 красавіка 1934 года. На сходзе, якім кіраваў А. Луцкевіч, былі выказаны абвінавачванні ў бок Р. Астроўскага ў неэтычных паводзінах і фінансавых злоўжываннях, а менавіта - у прысваенні грашовых сродкаў студэнцкай карпарацыі «Скарынія», выдадзеных ёй уладамі. Паводле пастановы сходу, Р. Астроўскага выключылі са складу БНТ да правядзення разбіральніцтва ў гэтай справе ${ }^{54}$. А. Луцкевіч, А. Трэпка і У. Самойла выклікалі яго на грамадскі суд для вырашэння ўсіх узаемных абвінавачванняў. Са свайго боку прыхільнікі Р. Астроўскага 17 красавіка 1934 года выключылі са складу ТБА сваіх апапентаў. 24 красавіка таго ж года Р. Астроўскі абвясціў аб сваім удзеле ў грамадскім судзе ${ }^{55}$. Неабходна адзначыць, што на яго бок перайшлі ТБА, Аб'яднанне беларускіх жанчын, Беларускае дабрачыннае таварыства, рэдакцыя газеты «Родны край». А. Луцкевіч захаваў уплыў толькі на Беларускае навуковае таварыства ${ }^{56}$.

Грамадскі суд паміж А. Луцкевічам і Р. Астроўскім праходзіў амаль паўтара года і закончыўся 14 лістапада 1935 года. Прысуд, вынесены грамадскім судом, не апраўдаў Р. Астроўскага. У ім было адзначана, што Р. Астроўскі на працягу 1930-1934 гадоў «хаатычна і арбітральна» распараджаўся грашыма розных беларускіх устаноў, а яго адносіны да беларускіх студэнтаў і цэлага шэрагу дзеячаў мелі характар «дэмаралізуючы ў сэнсе грамадскім» ${ }^{57}$. Правядзенне грамадскага суда адлюстравала канчатковы распад групы Луцкевіча-Астроўскага як асобнай палітычнай сілы ў Заходняй Беларусі. Тым не менш, палітычны кірунак, які прадстаўляла «беларуская са-

${ }^{53}$ Ibidem, арк. 69-70.

${ }^{54}$ P. Radosław Ostrowski, „Słowo” 1935, nr 322, s. 6; Walne zebranie Białoruskiego Towarzystwa Naukowego, „Kurjer Wileński” 1934, nr 105, s. 3.

${ }_{55}$ Р. Астроўскі, Адкрытае пісьмо, «Родны край» 1934, nr 8, с. 2.

${ }^{56}$ K. Gomółka, op. cit., s. 71.

${ }^{57}$ БДАМЛіМ, ф. 3, воп. 1, спр. 270, арк. 211. 
нацыя», працягваў існаваць у грамадска-палітычным жыцці, а яго галоўнымі прадстаўнікамі выступалі ТБА і група прыхільнікаў Р. Астроўскага.

Нягледзячы на атрыманае паражэнне і негатыўную рэпутацыю, Р. Астроўскі не страціў свайго аўтарытэту сярод пэўных колаў беларускага грамадства, асабліва сярод настаўнікаў ВБГ і часткі студэнтаў. У гэтае асяроддзе ўваходзілі, напрыклад, С. Кароль, Б. Кіт, К. Глінскі, У. Манкевіч, Х. Ілляшэвіч, Я. Шнаркевіч, А. Мілер і інш., якія імкнуліся рэабілітаваць Р. Астроўскага як палітычнага дзеяча ${ }^{58}$. 3 іншага боку, прыхільнікі А. Луцкевіча прыкладалі ўсе намаганні, каб не толькі дыскрэдытаваць свайго праціўніка, але і ўвогуле назаўсёды выключыць яго з беларускага грамадска-культурнага руху. Так, А. Луцкевіч і яго аднадумцы дамагаліся ў інспектара Віленскай навучальнай акругі звальнення Р. Астроўскага з пасады дырэктара ВБГ ${ }^{59}$.

Раскол і супрацьстаянне ўнутры «беларускай санацыі» негатыўна адбіліся на стане ТБА і яго ўплывах на культурна-асветнае жыццё Заходняй Беларусі. Фактычна ў 1934-1935 гадах таварыства знаходзілася ў стане «летаргічнага сну» і не праяўляла шырокай дзейнасці, калі не ўлічваць удзел прадстаўнікоў ТБА ў рабоце камісіі па падрыхтоўцы беларускіх падручнікаў для пачатковых школ Віленскай навучальнай акругі ${ }^{60}$. Р. Астроўскі працягваў палітыку «беларускай санацыі» па супрацоўніцтве 3 польскімі ўладамі, якую разлічваў нават пашырыць ${ }^{61}$.

Аднак у сярэдзіне 1930-х гадоў «беларуская санацыя» па прычыне ўнутраных канфліктаў і адстутнасці вялікай папулярнасці сярод беларусаў страціла апеку польскіх улад. Фактычна з кожным

${ }^{58}$ LCVA, f. 53, ap. 23, b. 2005, 1. 7-7 ant.

${ }^{59}$ Sprawozdanie z życia mniejszości narodowych za IV kwartał 1935 r., Warszawa 1936, s. 49.

${ }^{60}$ W. Paprocka, Białoruskie organizacje społeczno-kulturalne na Kresach Wschodnich w II Rzeczypospolitej, „Etnografia Polska” 1999, t. XLIII, z. 1-2, s. 13.

${ }^{61}$ K. Gomółka, op. cit., s. 71-72. 
месяцам субсідыі для ТБА і групы Р. Астроўскага змяншаліся ${ }^{62}$. Нельга пакінуць без увагі і той факт, што зніжэнне ўрадавай падтрымкі для ТБА было неразрыўна звязана 3 паваротам палітыкі ўлад да адкрытай паланізацыі і фактычнай ліквідацыі «беларускай праблемы» ў Польшчы ў другой палове 1930-х гадоў. Вынікі гэтай палітыкі закранулі не толькі беларускія нацыянальна-дэмакратычныя і культурныя арганізацыі (ТБШ, БІГіК, БНК), але нават і паланафільскі кірунак беларускага руху ${ }^{63}$.

У тых умовах дзеячы ТБА пачалі шукаць спробы рэфармавання таварыства. Некаторыя 3 іх прапаноўвалі змяніць палітычны тон ТБА на больш востры адносна іншых беларускіх арганізацый, што дало б магчымасць атрымаць неабходныя ўрадавыя субсідыі ${ }^{64}$. Злабадзённым было пытанне змены кіраўніцтва арганізацыі. 3'явілася група палітыкаў маладой генерацыі на чале 3 магістрам права К. Глінскім, якая імкнулася абнавіць кіруючы склад ТБА ${ }^{65}$. 1 сакавіка 1936 года быў скліканы гадавы сход рады ТБА, на якім адбылося абранне новага прэзідыума арганізацыі. У яго склад увайшлі К. Глінскі (старшыня), Б. Кіт (віцэ-старшыня), П. Шчасны (скарбнік), А. Мілер (сакратар) і М. Маркевіч (інструктар) ${ }^{66}$. Новае кіраўніцтва зрабіла некалькі крокаў для ажыўлення працы ТБА: аднавіла выданне газеты «Родны край» і паспрабавала стварыць у Вільні адзіны гурток таварыства ${ }^{67}$.

Аднак прыход новага кіраўніцтва не змог у значнай ступені актывізаваць дзейнасць ТБА і ўзмацніць яго пазіцыі ў грамадскім жыцці. Дыстанцыя, якую трымалі дзеячы таварыства да намаганняў ТБШ і БІГіК арганізаваць «школьную акцыю», прывяло да

${ }^{62}$ LCVA, f. 53, ap. 23, b. 2005, 1.9.

${ }^{63}$ А. Вабішчэвіч, Нацыянальна-культурнае жыциё..., с. 60.

${ }^{64}$ LCVA, f. 53, ap. 23, b. 2005, 1. 15.

${ }^{65}$ Ibidem, 1. 13.

${ }^{66}$ Sprawozdanie z życia mniejszości narodowych za II kwartat 1936 r., Warszawa 1936, s. 43.

${ }^{67}$ Беларуская хроніка, «Родны край» 1936, № 6, с. 3. 
яшчэ большага звужэння яго сацыяльнай базы. Апошнім ударам для прадстаўнікоў «беларускай санацыі» і арганізацыйнай структуры ТБА стаў перавод Р. Астроўскага з Вільні на пасаду настаўніка ў Лодзь, ажыццёўлены на загад віленскага ваяводы Л. Бацяньскага 31 жніўня 1936 года ${ }^{68}$. Не выключана, што гэты перавод быў выкліканы пэўнымі захадамі прыхільнікаў А. Луцкевіча. Тым не менш, унутры ТБА гэтую падзею расцанілі як крок улад у кірунку канчатковага згортвання беларуска-польскага супрацоўніцтва. У перадавым артыкуле газеты «Родны край» падкрэслівалася: «Пераводам гр. Астроўскага нанесены цяжкі ўдар польска-беларускаму паразуменню... Гр. Р. Астроўскі належыць якраз да той групы беларусаў, якая лічыць неабходным польска-беларускае збліжэнне. I вось цяпер, з пераводам Астроўскага ў Лодзь, у шмат каго з гэтай групы можа 3'явіцца сумненне ў мэтазгоднасці гэтай працы» ${ }^{69}$.

Спыненне ўзаемаадносін з уладамі, адсутнасць рэальнай падтрымкі насельніцтва і палітычных дзеячаў, уцягванне ў палітычную барацьбу замест правядзення асветнай дзейнасці прывялі да канчатковага заняпаду ТБА. 20 жніўня 1937 года яно было афіцыйна ліквідавана загадам віленскіх ваяводскіх улад, падзяліўшы лёс іншых беларускіх культурна-асветных і палітычных арганізацый таго часу ${ }^{70} .3$ ліквідацыяй ТБА спыніла сваё існаванне група праўрадавых дзеячаў «беларускай санацыі», якая на працягу амаль васьмі гадоў марна спрабавала знайсці кампраміс з санацыйнымі ўладамі дзеля захавання і пашырэння беларускай культурнай прысутнасці на г. зв. Kresach Wschodnich.

У беларускай савецкай і пасляваеннай эміграцыйнай гістарыяграфіі дзейнасць «беларускай санацыі» ў 1930-я гады ацэньвалася выключна негатыўна. Тым не менш, не адмаўляючы некаторых

${ }^{68} \mathrm{~V}$. Kalush, In the service of the people for a free Byelorussia. Biographical notes on professor Radoslav Ostrowski, London 1964, p. 31.

69 Дзіууна і незразумела, «Родны край» 1936, № 14, с. 1.

${ }^{70}$ А. Вабішчэвіч, Таварыства беларускай..., с. 488. 
3 гэтых ацэнак, неабходна прызнаць, што «беларуская санацыя» ў 1930-я гады, у адрозненне ад ранейшых беларускіх паланафільскіх арганізацый, змагла выпрацаваць паслядоўную праграму дзеянняў на палітычнай сцэне Заходняй Беларусі. Асновай гэтай праграмы было даволі справядлівае патрабаванне падтрымкі нацыянальнага жыцця беларусаў, як грамадзян Польшчы, з дзяржаўнага бюджэту і захаванне культурна-асветных устаноў. Аднак унутраныя рознагалоссі, нежаданне некаторых кіраўнікоў (перш за ўсё Р. Астроўскага) ісці на збліжэнне $з$ іншымі нацыянальнымі сіламі і бескампрамісная пазіцыя ўлад адносна беларускага насельніцтва не далі магчымасці «беларускай санацыі» да канца рэалізаваць намечаныя праграмныя мэты.

\section{Архіўныя крыніцы}

Lietuvos centrinis valstybės archyvas, f. 51, ap. 7, b. 1008 „Redagowanie czasopism pod tytułem «Napierad», «Narodny Zwon», «Białoruski Zwon» (19291932); b. 979 „Redagowanie czasopisma pod tytułem «Hołas prawosławnoho Biełarusa» (1932)”; f. 53, ap. 23, b. 1074 ,Sprawozdania sytuacyjne z życia społecznego i politycznego m. Wilno (1931)”; b. 1075 ,Sprawozdania sytuacyjne z życia społecznego i politycznego m. Wilno (1931)"; b. 2005 „Akta w sprawie rejestracji i likwidacji związków i stowarzyszeń (statuty, sprawozdania, protokoły, korespondencja). Towarzystwo Oświaty Białoruskiej (1927-1935)”; b. 2078 „Akta w sprawie rejestracji i likwidacji związków i stowarzyszeń (statuty, sprawozdania, protokoły, korespondencja). Związek białoruskich kulturalno-oświatowych i gospodarczych organizacji i instytucji (1928-1937)”; f. 131, ap. 2, b. 1645 „Sprawy osób oskarżonych za działalność komunistyczną. Taraszkiewicz Bronisław (1931-1933)".

Беларускі дзяржаўны архіў-музей літаратуры і мастацтва, ф. 3, воп. 1, спр. 31 «Статут Таварыства беларускай асветы ў г. Вільня (1932 г.)»; спр. 270 «Дакументы грамадскага суда Р. Астроўскага супраць А. Луцкевіча, У. Самойлы, А. Трэпкі (1934-1935 гг.).

Нацыянальны архіў Рэспублікі Беларусь, ф. 242п, воп. 1, спр. 30 «Материалы по национально-освободительному движению в Западной Белоруссии и газета „Большевик” (1924-1935 гг.)»; спр. 435 «Обзор состояния и деятельности белорусских национально-политических фашистских группировок в Западной Белоруссии и др. (1932-1933 гг.)». 


\section{Літаратура}

Białorusini, „Sprawy Narodowościowe” 1928, nr 1.

Białorusini, „Sprawy Narodowościowe” 1928, nr 3-4.

Białorusini, „Sprawy Narodowościowe” 1928, nr 5.

Gomółka K., Białoruskie partie i organizacje prorzadowe w II Rzeczypospolitej, „Białoruskie Zeszyty Historyczne” 1997, t. 7.

Kalush V., In the service of the people for a free Byelorussia. Biographical notes on professor Radoslav Ostrowski, London 1964.

Mniejszości narodowe w wyborach do Sejmu i Senatu w r. 1928, Warszawa 1928.

P. Radosław Ostrowski, „Słowo” 1935, nr 322.

Paprocka W., Białoruskie organizacje społeczno-kulturalne na Kresach Wschodnich w II Rzeczypospolitej, „Etnografia Polska” 1999, t. XLIII, z. 1-2.

Sejm Rzeczypospolitej Polskiej. Okres II. Sprawozdanie stenograficzne z 31 posiedzenia z dnia 16 listopada 1928 r., Warszawa 1928.

Sprawozdanie z życia mniejszości narodowych za II i III kwartat 1930 r., Warszawa 1930.

Sprawozdanie z życia mniejszości narodowych za II kwartał 1936 r., Warszawa 1936.

Sprawozdanie z życia mniejszości narodowych za IV kwartat 1935 r., Warszawa 1936.

Walne zebranie Białoruskiego Towarzystwa Naukowego, „Kurjer Wileński” 1934, nr 105.

Wappa E., Okoliczności powstania Centralnego Związku Białoruskich Organizacji i Instytucji Kulturalno-Oświatowych (,,Centrasajuzu”) i jego udziat w wyborach 1930 r., „Białoruskie Zeszyty Historyczne” 1994, t. 1.

Z biełaruskaha žyćcia, „Biełaruskaja krynica” 1929, nr 23.

1-ая сэсія Галоўнай Рады Беларускага «Цэнтрасаюзу», «Наперад» 1930, № 27.

А. С., Мітрапалітальная Рада, «Беларуская зарніца» 1928, № 1.

Ад рэдакиьыi, «Наперад» 1929, № 1.

Акінчыц Ф., Пісьмо ў рэдакиыю, «Наперад» 1930, № 27.

Акінчыц Ф., Чаму гэта так сталася?, Вільня 1931.

Астроўскі Р., Адкрытае пісьмо, «Родны край» 1934, № 8.

Барачьба з беларускасьияй у БССР, «Наперад» 1930, № 19.

Беларуская справа і польскае грамадзянства, «Беларускі звон» 1931, № 7.

Беларуская хроніка, «Родны край» 1936, № 6.

Вабішчэвіч А., Наџыянальна-культурнае жыциё у Заходняй Беларусі (19211939 гг.): дыссертаџыя доктара гістарычных навук, Брэст 2010. 
Вабішчэвіч А., Таварыства беларускай асветы [у:] Энцьиклапедыя гісторыі Беларусі. У 6 m. Т. 6. Кн. 1, рэд. Г. Пашкоў, Мінск 2001.

Горны А., Беларускі Цэнтрасаюз і Ф. Акінчыц (1930-1931 гг.): ад лідарства да варожасиі [w:] Polsko-białoruskie związi językowe, literackie, historyczne i kulturowe: Materiaty XIX międzynarodowej konferencji naukowej „Droga ku wzajemności”, red. B. Siegień, Białystok 2014.

Да падзеяў у Віленскай беларускай гімназіі, «Бальшавік» 1929, № 3.

Дзіўна і незразумела, «Родны край» 1936, № 14.

3 жыцьия Цэнтрасаюзу, «Беларускі звон» 1931, № 4.

За мінуль год, «Родны край» 1933, № 25.

Заява, пададзеная гр. Акінчыцам у Прэзыдыюм Б. Ц. Саюзу, «Беларуская праўда. Аднаднёўка» 1931, 12 мая.

«Калгасы» ў БССР, «Наперад» 1930, № 8.

Ладысеў У., Беларуская санащыл [у:] Энщылклапедыя гісторыі Беларусі. У 6 m. Т. 1, рэдкал.: М. Біч [і інш.], Мінск 1993.

Ладысеў У., Брыгадзін П., Паміж Усходам і Захадам. Станаўленне дзяржаўнасиі і тэрытарыяльнай иэласнасиі Беларусі (1917-1939 г2.), Мінск 2003.

Ладысеў У., Шлях да свабоды: з гісторыі рэвалюиьийна-вызваленчага руху у Заходняй Беларусі у 1919-1939 г2., Мінск 1978.

Латышонак А., Мірановіч Я., Гісторыя Беларусі ад сярэдзіны XVIII cm. да пачатку XXI cm., Białystok, Vilnius 2010.

Левин М., Белорусская саначия (Луикевич - Островский) [в:] Политические партии в Польше, Западной Белоруссии и Западной Украине, ред. С. Скульского, Минск 1935.

Луцкевіч А., Да гісторыі беларускага руху, Białystok, Vilnius 2010.

Наша хроніка. Беларуская санаџыя у новай ролі, «Да працы» 1928, № 2.

Ня слоў, а дзела!, «Наперад» 1929, № 3.

Полуян В., Революиионно-демократическое движение в Западной Белоруссии (1927-1939 г2.), Минск 1978.

Полярызаџыя сілаў, «Слова працы» 1928, № 7.

Сваімі сіламі, «Наперад» 1930, № 6.

Сідарэвіч А., Хроніка пераломнага часу: Антон Луцкевіч як ідэолаг і правадыр нацыяянал-фашызму і начьяянал-дэмакратыі, «Дзеяслоў» 2004, № 8.

Склубоўскі В., 3 мінульхх год, «Ніва» 1982, № 25.

Сталевіч А., Польскі фашызм ратуециа бельмм тэрорам, «Савецкая Беларусь» 1929, № 38 . 
Статут Цэнтральнага Саюзу Беларускіх Культурна-Прасьветных і Гаспадарскіх Арганізаиыяу і Інстытуиььяў, Вільня 1930.

Туронак Ю., Мадэрная гісторыя Беларусі, Vilnius 2006.

Узмацненьне клерыкалізму, «Рэха працы» 1928, № 5.

Цень Азэфа, «Наперад» 1930, № 7.

Цэнтрасаюз і яго праиа [у:] Беларускі каляндар на 1932 г., Вільня [б. г.].

Эра [Астроўскі Р.], Яшчэ адна - можа апошняя - спроба, «Наперад» 1930, № 21.

\section{"Belarusian sanation" in Poland (1928-1937): between confrontation and loyality}

A number of political trends existed in the Belarusian national movement in Western Belarus in Poland in the interwar period. One such political trend was the "Belarusian sanation" ("Luckievič-Astroǔski group"), which arose after the Polish authorities dissolved the Belarusian Peasants Workers Hramada. Followers of the "Belarusian sanation" proposed to abandon the radical political struggle and begin a search for a compromise with the Polish authorities to preserve the existing Belarusian cultural and educational organizations. Based on these ideas, such organizations as Centrasajuz and the Belarusian Education's Association were created. At the same time, the "Belarusian sanation" was quite critical of polonization policy and acted as a"constructive opposition" towards the Polish authorities. The reason for the decline of the "Belarusian sanation" was internal disagreement among the leaders of this political direction.

Keywords: Belarusian national movement, Western Belarus, interwar Poland, "Belarusian sanation", Luckievič-Astroŭski group 